\title{
Diversity and Distribution of Rice Blast (Pyricularia oryzae Cavara) Races in Bangladesh
}

M. A. I. Khan, M. A. Ali, and M. A. Monsur, Bangladesh Rice Research Institute, Gazipur-1701, Bangladesh; A. Kawasaki-Tanaka, Tottori University, 4-101 Koyama-Minami Tottori, Tottori 680-8553, Japan; N. Hayashi, National Institute of Agrobiological Sciences, 2-1-2 Kannondai, Tsukuba, Ibaraki, 305-8602, Japan; S. Yanagihara and M. Obara, Japan International Research Center for Agricultural Sciences, 1-1, Ohwashi, Tsukuba, Ibaraki 305-8686, Japan; M. A. T. Mia and M. A. Latif, Bangladesh Rice Research Institute; and Y. Fukuta, Tropical Agriculture Research Front, Japan International Research Center Agricultural Sciences, 1091-1, Kawarabaru, Aza Maezato, Ishigaki, Okinawa 907-0002, Japan

\begin{abstract}
Khan, M. A. I., Ali, M. A., Monsur, M. A., Kawasaki-Tanaka, A., Hayashi, N., Yanagihara, S., Obara, M., Mia, M. A. T., Latif, M. A., and Fukuta, Y. 2016. Diversity and distribution of rice blast (Pyricularia oryzae Cavara) races in Bangladesh. Plant Dis. 100:2025-2033.

The pathogenicity of 331 blast isolates (Pyricularia oryzae Cavara) collected from different regions and ecosystems for rice cultivation in Bangladesh was evaluated by compatibility on 23 differential varieties (DV), each harboring a single blast resistance gene, and susceptible 'Lijiangxintuanheigu' (LTH). A wide variation in virulence was found among the isolates, and 267 races were classified using a new designation system. Virulence of blast isolates against DV carrying the resistance genes Pia, Pib, Pit, Pik-s, Piz-t, Pi12(t), Pi19(t), and Pi20(t), as well as avirulence against those carrying Pish, Pi9, Pita-2, and Pita, was distributed widely in Bangladesh. Cluster analysis of the compatibility data on the DV initially classified the isolates into groups I and II.

The virulence spectra of the two groups differed mainly according to the reactions of the DV to Pii, Pi3, Pi5(t),Pik-m, Pil, Pik-h,Pik, Pik-p, and $P i 7(\mathrm{t})$. Group I isolates were distributed mainly in rainfed lowlands, whereas group II isolates were found mainly in irrigated lowlands; however, there were no critical differences in geographic distribution of the blast isolates. In total, 26 isolates, which could be used to identify the 23 resistance genes of the DV on the basis of their reaction patterns, were selected as a set of standard differential blast isolates. To our knowledge, this is the first clear demonstration of the diversity and differentiation of blast races in Bangladesh. This information will be used to develop a durable blast protection system in that country.
\end{abstract}

Rice blast disease caused by Pyricularia oryzae Cavara is one of the major factors limiting rice yield (Oryza sativa L.) throughout the world (Bonman 1992a; Marchetti et al. 1976; Mekwatanakarn et al. 1999; Ou 1985). This pathogen infects all developmental stages and all organs of the rice plant (Le et al. 2010; Ou 1985). Outbreaks of the disease are a recurrent problem and are extremely difficult to control in all rice-growing regions of the world, including Bangladesh (Dean et al. 2005; Khan et al. 2014a; Talbot 2003; Valent and Chumley 1991). Bangladesh has experienced several epidemic outbreaks of blast disease since 1980 (Ahmed et al. 1985; Shahjahan 1994). Khan et al. (2014b) reported that most of the cultivars popular in Bangladesh, including aromatic rice varieties, in both rainfed and irrigated lowlands were highly susceptible to blast.

Breeding rice cultivars resistant to blast disease is the most ecofriendly and economic approach to managing the disease. However, because of the continuous generation of new pathogenic races, cultivars released as resistant have often shown high levels of susceptibility within a few years of their release (Bonman 1992b; Koizumi 2008; Mekwatanakarn et al. 1999; Zeigler et al. 1995; Zhou et al. 2007). Based on the gene-for-gene theory, outbreaks can be explained in terms of the relationships between virulence genes in the blast fungus and resistance genes in rice cultivars (Flor 1971; Silué et al. 1992). To understand the mechanisms behind outbreaks of resistant blast disease and the build-up of a durable protection system in rice cultivars, knowledge of the population structure and diversity of the blast

Corresponding author: Y. Fukuta; E-mail: zen@affrc.go.jp

*The $\boldsymbol{e}$-Xtra logo stands for "electronic extra" and indicates that one supplementary table is published online.

Accepted for publication 9 May 2016.

http://dx.doi.org/10.1094/PDIS-12-15-1486-RE

(C) 2016 The American Phytopathological Society pathogen is important. Some sets of differential varieties (DV) have already been developed in rice (Atkins et al. 1967; Kiyosawa 1984; Ling et al.1995; Mackill and Bonman1992; Telebanco-Yanoria et al. 2010; Tsunematsu et al. 2000; Yamada et al. 1976) and have been used widely for pathogenicity studies. From among these sets of DV, the International Rice Research Institute-Japan Collaborative Research Project developed monogenic lines with the genetic background of the susceptible japonica-type 'Lijiangxintuanheigu' (LTH) as a set of international DV. These DV each contain one of 23 blast resistance genes: namely, Pish, Pib, Pit, Pia, Pii, Pi3, Pi5(t), Pik-s, Pik-m, Pil, Pik-h, Pik, Pik-p, Pi7(t), Pi9, Piz, Piz-5, Piz-t, Pita-2, Pita, Pi12(t), Pi19(t), and Pi20(t) (Fukuta et al. 2004; Kobayashi et al. 2007; Tsunematsu et al. 2000). Moreover, Telebanco-Yanoria et al. (2010) developed near isogenic lines (NIL) with an LTH genetic background as advanced DV, each harboring one of 11 resistance genes: namely, Pib, Piz-5, Pi9, Pi3, Pia, Pik-s, Pik, Pik-h,Pi7(t), Pita, and Pita-2. By using these DV, more precise evaluation of the pathogenicities of blast isolates has become possible. Hayashi and Fukuta (2009) proposed a new designation system for blast races using the $23 \mathrm{DV}$ and LTH. Recently, the pathogenicity of blast isolates from Cambodia, West Africa, and Japan using the 23 or 11 DV was reported (Fukuta et al. 2014; Odjo et al. 2014; Kawasaki-Tanaka et al. 2016).

Information about the distribution and differentiation of blast races is vital for developing a durable system of protection against blast disease. Here, we used monogenic lines (Fukuta et al. 2004; Kobayashi et al. 2007; Tsunematsu et al. 2000) and LTH NIL (Telebanco-Yanoria et al. 2010) to characterize the pathogenicities of blast isolates collected from two major rice-growing ecosystems and all of the rice-growing administrative divisions of Bangladesh. Thus, we clarified the diversity and distribution of blast races in Bangladesh. We then used the pathogenicity data to make a preliminary selection of standard differential blast isolates (SDBI), which can be used to identify and characterize resistance genes in rice cultivars. The set of DV and SDBI will be used as the first differential system for blast virulence and rice resistance studies in Bangladesh. 


\section{Materials and Methods}

Collection and isolation of blast isolates. In total, 1,200 blast isolates (P. oryzae Cavara) were collected from the infected leaves and panicles of 37 rice ( $O$. sativa L.) cultivars, including landraces, highyielding inbred lines, and hybrid rice. Sampling covered all of the administrative divisions of Bangladesh (Rangpur, Rajshahi, Sylhet, Dhaka, Khulna, Barisal, and Chittagong) where rice is cultivated and two major rice-growing ecosystems for rice cultivation (rainfed lowland and irrigated lowland) from 2009 to 2012. Single spores were isolated from infected leaves or panicles incubated on moist filter paper in a petri dish at room temperature for $24 \mathrm{~h}$ in accordance with the protocols of Hayashi et al. (2009). Colonies from single conidia were grown on water agar for 5 to 7 days; two or three cut pieces of single colony were then transferred to sterile filter paper placed on rice straw agar medium. Finally, to enable repeated access to the original isolates, the fungi were grown on filter paper and stored aseptically in filter paper at $-20^{\circ} \mathrm{C}$ after the necessary drying. Details of each isolate used in this study are presented in Supplementary Table S1.

Of the isolates collected, 331 were arbitrarily selected as representatives of single fields and used in pathogenicity test. In the 3 years in which this study was done, blast infection was observed in the rainfed lowlands during the Aman season from July to December, and the irrigated lowlands during the Boro season from November to May. It was not present in the Aus season, which occurs from April to July.

DV. An international set of DV comprising 23 monogenic lines (Kobayashi et al. 2007; Tsunematsu et al. 2000) carrying 21 resistance genes, two NIL with the LTH genetic background (Telebanco-Yanoria et al. 2010), and LTH as susceptible check was used. The virulence of the isolates was determined based on the reaction of the $25 \mathrm{DV}$ and LTH.

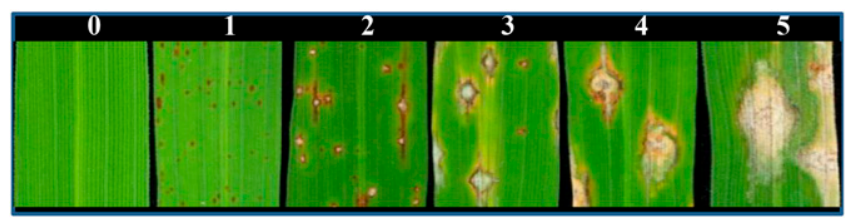

Fig. 1. Pictorial view of disease rating scale ( 0 to 5 ) of blast disease to Lijiangxintuanheigu LTH monogenic lines (Hayashi and Fukuta, 2009).
Inoculation and scoring of infection. To produce inocula, stock isolates (on paper discs) were cultured on oatmeal agar medium. The inoculated plates were incubated at 25 to $28^{\circ} \mathrm{C}$ for 12 to 14 days. The culture was scraped with a sterilized toothbrush, and the plates were then exposed to continuous light for 4 or 5 days to induce heavy sporulation. Conidia were dislodged by gentle rubbing with a paintbrush from incubated plates into sterilized distilled water with $0.01 \%$ Tween 20. Spore suspensions were filtered through four layers of gauze mesh; the concentration was adjusted to $10 \times 10^{4}$ conidia $/ \mathrm{ml}$ by using a hemocytometer (Hayashi et al. 1998; Tuite 1969).

Inoculation of the $25 \mathrm{DV}$ and LTH (susceptible check) with the blast isolates was performed under greenhouse conditions following the methods of Bonman et al. (1986) and Hayashi et al. (2009). Seed of these varieties were treated using $0.5 \%$ Benlate T20 and then soaked for 1 to 2 days in water. Imbibed seed were sown in a plastic cell tray at 3 seeds/cell ( $\varphi 16$ by $25 \mathrm{~mm}, 5$ by 7 cells) and were maintained in the greenhouse. Inoculation was done by placing a seedling cell tray containing 20- to 21-day-old seedlings (at about the four- or five-leaf stage) on a rotating plate, spraying the seedlings uniformly with $10 \mathrm{ml}$ of spore suspension $\left(1 \times 10^{5}\right.$ spores $\left./ \mathrm{ml}\right)$ per tray using an electric fine atomizer (nozzle size $0.3 \mathrm{~mm}$; Airtex) at $0.1 \mathrm{MPa}$. Inoculated seedlings were incubated in a dew chamber at $25^{\circ} \mathrm{C}$ for $20 \mathrm{~h}$ and then transferred to a greenhouse maintained at $25 \pm 1^{\circ} \mathrm{C}$ and 70 to $80 \%$ relative humidity. The experiment was done twice.

The reaction of each DV and LTH with each blast isolate was evaluated 7 days after inoculation using six scores from 0 to 5 , where $0=$ no evidence of infection; 1 = brown specks smaller than $0.5 \mathrm{~mm}$ in diameter, no sporulation; 2 = brown specks about 0.5 to $1 \mathrm{~mm}$ in diameter, no sporulation; 3 = roundish to elliptical lesions about 1 to $3 \mathrm{~mm}$

Table 1. Cluster group distribution of blast isolates in each ecosystem of Bangladesh $^{\mathrm{a}}$

\begin{tabular}{lccc}
\hline & \multicolumn{3}{c}{ Number of blast isolates in each ecosystem $(\%)$} \\
\cline { 2 - 4 } Cluster & Rainfed lowland & Irrigated lowland & Total \\
\hline I & $147(44.4)$ & $21(6.4)$ & $168(50.8)$ \\
II & $28(8.5)$ & $135(40.7)$ & $163(49.2)$ \\
Total & $175(52.9)$ & $156(47.1)$ & $331(100.0)$ \\
\hline
\end{tabular}

${ }^{a}$ Cluster grouping was performed by hierarchical cluster analysis (Ward method), using the reaction patterns of differential cultivars to blast isolates.

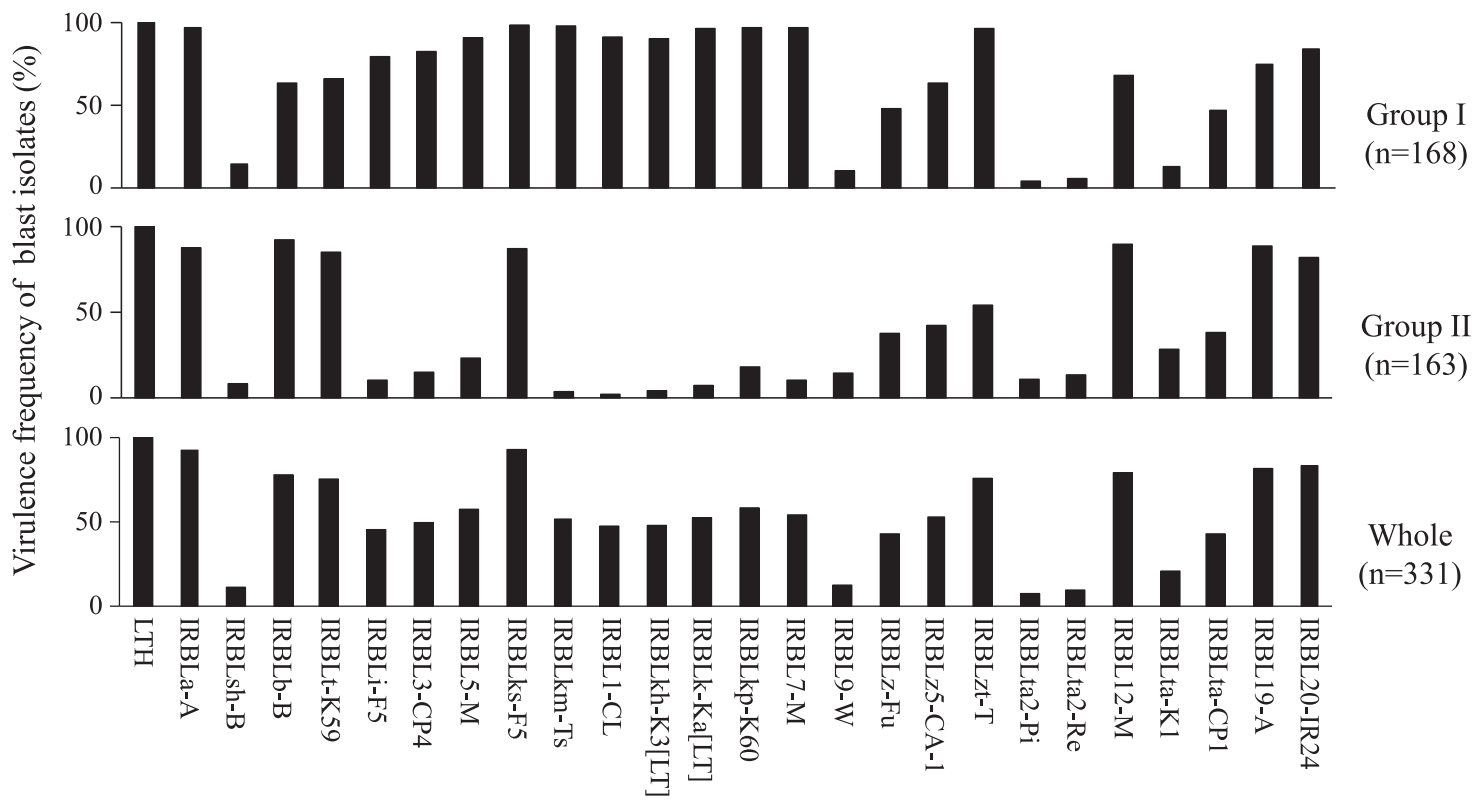

Differential variety and susceptible check (LTH)

Fig. 2. Virulence frequencies of blast isolates from each cluster group on differential rice varieties. Cluster analysis using Ward's hierarchical clustering method was used to classify a total of 331 blast isolates on the basis of the reaction pattern of 25 differential varieties as well as Lijiangxintuanheigu (LTH) for susceptibility checking. 
in diameter, with gray centers surrounded by brown margins, lesions capable of sporulation; 4 = typical spindle-shaped blast lesions capable of sporulation, $3 \mathrm{~mm}$ or longer, with necrotic gray centers and water-soaked or reddish brown margins, little or no coalescence of lesions; and $5=$ lesions as in 4 but about half of one or two leaf blades killed by coalescing lesions (Fig. 1). Disease reactions that scored 0 to 2 were classified as resistant (R) while those scored 3 to 5 were classified as susceptible (S), with the exception of IRBLta2-Pi for Pita-2 (resistant $=0$ to 3) and IRBL5-M for Pi5(t) (resistant $=0$ to 1), in accordance with Hayashi and Fukuta (2009).

Race designation. Blast isolates based on the reaction patterns of $25 \mathrm{DV}$ and LTH were designated by following the designation system proposed by Hayashi and Fukuta (2009). The DV and LTH were categorized into five DV groups ("U”, "i", "k", “z”, and "ta”), where group U included LTH, IRBLa-A, IRBLsh-B, IRBLb-B, IRBLtK59, and LTH; group i included three lines with the Pii locus on chromosome 9; group $\mathrm{k}$ included seven lines with the Pik region on chromosome 11; group $\mathrm{z}$ included four lines with the Piz region on chromosome 6; and group ta included seven lines with the Pita region on chromosome 12 . The resistance genes in four of the DV groups (i, k, z, and ta) were multiple alleles or were located in the same chromosome regions. The remaining four genes-Pia on chromosome 11, Pish and Pit on chromosome 1, and Pib on chromosome 2-were located in different chromosome regions independently. In this study, we replaced the two monogenic lines used by Hayashi and Fukuta (2009) (namely, IRBLkh-K3 and IRBLk-Ka) with two LTH NIL (IRBLkh-K3[LT] and IRBLk-K[LT], respectively). In this way, each reaction type consisted of one to three units, to each of which we allocated three DV or three blast resistance genes. To designate the reaction type, we applied designation codes 1,2 , and 4 for susceptible reactions of each of the three respective DV to the blast isolates. The sum of these codes of each unit in each DV group designated a reaction type, representing the reactions of the DV in each group. Blast races were designated by the combined sum of the codes in each DV group, in accordance with Gilmour's method (Gilmour 1973). Isolates classified this way were designated by reaction types within

Table 2. Numbers of blast isolates of each reaction type, as categorized on the basis of the reactions of differential variety (DV) group $\mathrm{U}$

\begin{tabular}{|c|c|c|c|c|c|c|c|c|}
\hline \multirow{2}{*}{$\begin{array}{l}\text { Reaction } \\
\text { type }\end{array}$} & \multicolumn{5}{|c|}{ Rice resistance gene } & \multicolumn{3}{|c|}{$\begin{array}{l}\text { Number of virulent isolates (\%) } \\
\text { per blast isolate cluster group }\end{array}$} \\
\hline & Pish & $P i b$ & Pit & LTH & Pia & I & II & Total \\
\hline U03 & $\mathrm{a}$ & $\mathrm{a}$ & $\mathrm{a}$ & $\mathrm{v}$ & $\mathrm{v}$ & $31(9.3)$ & $0(0.0)$ & $31(9.3)$ \\
\hline $\mathrm{U} 23$ & $\mathrm{a}$ & $\mathrm{v}$ & $\mathrm{a}$ & $\mathrm{v}$ & $\mathrm{v}$ & $23(6.9)$ & $21(6.3)$ & $44(13.3)$ \\
\hline U43 & $\mathrm{a}$ & $\mathrm{a}$ & $\mathrm{v}$ & $\mathrm{v}$ & $\mathrm{v}$ & $26(7.8)$ & $9(2.7)$ & $35(10.5)$ \\
\hline U61 & $\mathrm{a}$ & $\mathrm{v}$ & $\mathrm{v}$ & $\mathrm{v}$ & $\mathrm{a}$ & $1(0.3)$ & $16(4.8)$ & $17(4.1)$ \\
\hline U63 & $\mathrm{a}$ & $\mathrm{v}$ & $\mathrm{v}$ & $\mathrm{v}$ & $\mathrm{v}$ & $59(17.8)$ & $100(30.2)$ & $159(48.0)$ \\
\hline U73 & $\mathrm{v}$ & $\mathrm{v}$ & $\mathrm{v}$ & $\mathrm{v}$ & $\mathrm{v}$ & $21(6.3)$ & $13(3.9)$ & $34(10.2)$ \\
\hline Others ${ }^{b}$ & $\cdots$ & $\ldots$ & $\ldots$ & $\ldots$ & $\ldots$ & $7(2.1)$ & $4(1.2)$ & $13(4.2)$ \\
\hline $\begin{array}{l}\text { Diversity } \\
\text { index }\end{array}$ & $\ldots$ & $\ldots$ & $\ldots$ & $\ldots$ & $\ldots$ & 0.78 & 0.59 & 0.72 \\
\hline
\end{tabular}

${ }^{a}$ Blast isolates were evaluated according to the reactions of DV groups, as classified by Hayashi and Fukuta (2009). v = virulent to DV or Lijiangxintuanheigu $(\mathrm{LTH})$ and $\mathrm{a}=$ avirulent to DV or LTH.

b Types U01, U21, U33, and U41.

${ }^{c}$ Diversity index was calculated by using the method of Simpson (1949).

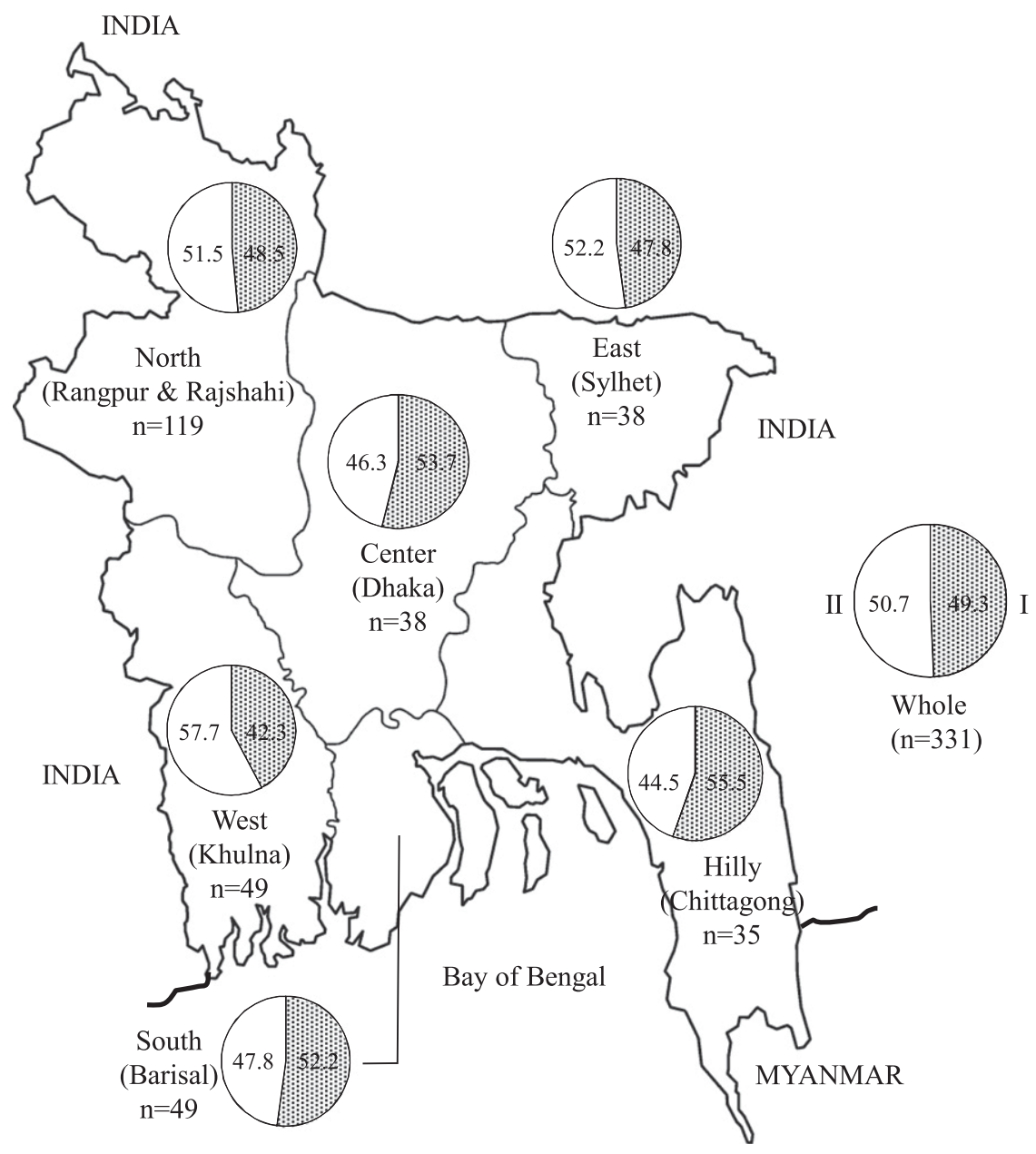

Fig. 3. Distribution of blast isolate pathogenicity groups in Bangladesh. Frequencies of blast isolates in each group are shown in six regions of Bangladesh; $n=$ number of isolates tested in each region and names in parentheses = names of administrative divisions. Shaded part of the pie chart indicates group I isolates and white part indicates group II isolates . 
each DV group such as "U63" and "U73" for DV group U or "k100" and " $\mathrm{k} 177$ " for DV group $\mathrm{k}$, and as races by using the set of reaction types of all DV groups (U63-i0-k100-z00-ta403).

Classification. Ward's hierarchical method (Ward 1963) and JMP (JMP 11.2 for Windows, 2014; SAS Institute, Inc.) were used to perform a cluster analysis on the basis of the data on the blast isolate infection scores of the $25 \mathrm{DV}$ and LTH. The relationships between the pathogenicities of the cluster groups and the ecosystems and geographical distributions were evaluated. Pathogen diversity was calculated by using Simpson's diversity index (Simpson 1949). The index value varied from 0 to 1 , where 0 represents no diversity and 1 is maximum diversity.

\section{Results}

Variation of blast isolates. We investigated the pathogenicities of 331 blast isolates on the basis of the reactions of LTH and of 25 DV harboring 23 resistance genes (Fig. 2). In all, 8 DV (for Pia, Pib, Pit, Pik-s, Piz-t, Pi12(t), Pi19(t), and Pi2O(t)) showed comparatively high blast virulence frequencies (>60\%), 12 DV (for Pii, Pi3, Pi5(t), Pik-m, Pi1, Pik-h, Pik, Pik-p, Pi7(t), Piz, Piz-5, and Pita(CP1)), had intermediate frequencies (20 to 60\%), and $5 \mathrm{DV}$ (for Pish, Pi9, Pita-2(2), and Pita(KI)), had low frequencies $(<20 \%)$. LTH was susceptible to all blast isolates.

Classification of blast isolates. The 331 tested blast isolates were classified by cluster analysis into two major groups on the basis of the reaction patterns of the DV and LTH (Table 1; Fig. 2). In total, 168 isolates $(50.8 \%)$ were classified into group I and 163 isolates $(49.2 \%)$ were classified into group II. There were differences in the virulence frequencies among the isolates of group I and group II to DV. The virulence frequencies of blast isolates in group I were markedly higher than those of group II against nine DV (for Pii, Pi3, Pi5(t), Pik-m, Pil, Pik-h, Pik, Pik- $p$, and Pi7(t)). The virulence frequencies of blast isolates in group I against four other DV (for Pish, Piz, Piz-5, and $P i z-t$ ) were also higher than those of group II. In contrast, the virulence frequencies of blast isolates in group I against the DV for Pib,

Table 3. Numbers of blast isolates of each reaction type, as categorized on the basis of the reactions of differential variety (DV) group $i$

\begin{tabular}{lccccccc}
\hline & \multicolumn{3}{c}{$\begin{array}{c}\text { Rice resistance } \\
\text { gene }\end{array}$} & & \multicolumn{2}{c}{$\begin{array}{c}\text { Number of virulent isolates (\%) } \\
\text { per blast isolate cluster group }\end{array}$} \\
\cline { 2 - 3 } \cline { 6 - 8 } Reaction type & $\boldsymbol{P i i}$ & $\boldsymbol{P i 3}$ & $\boldsymbol{P i 5 ( t )}$ & & I & II & Total \\
\hline i0 & $\mathrm{a}$ & $\mathrm{a}$ & $\mathrm{a}$ & & $12(3.6)$ & $109(32.9)$ & $121(36.5)$ \\
i4 & $\mathrm{a}$ & $\mathrm{a}$ & $\mathrm{v}$ & & $12(3.6)$ & $23(6.9)$ & $35(10.5)$ \\
i7 & $\mathrm{v}$ & $\mathrm{v}$ & $\mathrm{v}$ & & $131(39.6)$ & $14(4.2)$ & $145(43.8)$ \\
Others $^{\mathrm{b}}$ & $\ldots$ & $\ldots$ & $\ldots$ & & $13(3.9)$ & $17(5.1)$ & $30(9.1)$ \\
Diversity index $^{\mathrm{c}}$ & $\ldots$ & $\ldots$ & $\ldots$ & & 0.38 & 0.52 & 0.66 \\
\hline
\end{tabular}

a Blast isolates were evaluated according to the reactions of DV groups, as classified by Hayashi and Fukuta (2009). v = virulent to DV or Lijiangxintuanheigu (LTH) and a $=$ avirulent to DV or LTH

b Types i1, i2, i3, i6, and i5.

c Diversity index was calculated by using the method of Simpson (1949).
Pit, Pi12(t), Pi19(t), and Pita(K1) were lower than those of group II. In the case of six DV (for Pik-s, Pi9, Pita-2(P1), Pita-2(Re), Pita $(\mathrm{CP} 1)$, and $P 20(\mathrm{t}))$ the virulence frequencies did not differ greatly between group I and II isolates.

Geographic distribution of blast isolates. In total, 147 blast isolates $(44.4 \%$ of the total) from rainfed lowland were classified into group I and $28(8.5 \%)$ from this ecosystem were classified into group II. In contrast, 21 isolates $(6.4 \%)$ from irrigated lowland were categorized into group I and $135(40.7 \%)$ from this ecosystem were categorized into group II (Table 1). Thus, the frequencies of the two groups of blast isolates virulent to DV differed completely between the rainfed and irrigated lowland systems.

Group I and II blast isolates had similar frequencies in the six geographic regions of Bangladesh: North, South, Central, East, West, and Hilly (Fig. 3).

Characterization of blast isolates on the basis of types of reaction of DV groups. Isolates were categorized by reaction type within each DV group and as races according to the reaction types of DV groups using the method proposed by Hayashi and Fukuta (2009). The cluster groups of blast isolates were then characterized according to the frequencies of occurrence of these reaction types (Tables 2 through 6).

In DV group $\mathrm{U}$, blast isolates were classified into 10 reaction types (namely, U01, U03, U21, U23, U33, U41, U43, U61, U63, and U73) on the basis of the reactions of the DV for Pish, Pib, Pit, LTH, and Pia. The six major reaction types (U03, U23, U43, U61, U63, and U73) included from 17 to 159 blast isolates (from 4.1 to $48.0 \%$ of the total). The other reaction types included only 13 isolates. The isolates of the reaction type of U03, which were virulent to the DV for Pia and to LTH, were found only in group I, and the frequencies of

Table 5. Numbers of blast isolates of each reaction type, as categorized on the basis of the reactions of differential variety (DV) group $\mathrm{z}$

\begin{tabular}{|c|c|c|c|c|c|c|c|}
\hline \multirow[b]{2}{*}{ Reaction type } & \multicolumn{4}{|c|}{ Rice resistance gene } & \multicolumn{3}{|c|}{$\begin{array}{l}\text { Number of virulent isolates } \\
(\%) \text { per blast isolate cluster } \\
\text { group }^{\mathbf{a}}\end{array}$} \\
\hline & $P i 9$ & $P i z$ & Piz-5 & $P i z-t$ & $\mathbf{I}$ & II & Total \\
\hline $\mathrm{z} 00$ & $\mathrm{a}$ & $\mathrm{a}$ & $\mathrm{a}$ & $\mathrm{a}$ & $47(1.2)$ & 37 (11.1) & $41(12.4)$ \\
\hline z02 & $\mathrm{a}$ & $\mathrm{a}$ & $\mathrm{v}$ & a & $1(0.3)$ & $14(4.2)$ & $15(4.5)$ \\
\hline z04 & $\mathrm{a}$ & $\mathrm{a}$ & $\mathrm{a}$ & $\mathrm{v}$ & 37 (11.1) & $29(8.7)$ & $66(19.9)$ \\
\hline z05 & a & $\mathrm{v}$ & $\mathrm{a}$ & $\mathrm{v}$ & $17(5.1)$ & $17(5.1)$ & $34(10.2)$ \\
\hline z06 & $\mathrm{a}$ & $\mathrm{v}$ & $\mathrm{a}$ & $\mathrm{v}$ & $40(12.0)$ & $15(4.5)$ & $55(16.6)$ \\
\hline z07 & $\mathrm{a}$ & $\mathrm{v}$ & $\mathrm{v}$ & $\mathrm{v}$ & $42(15.7)$ & $16(4.8)$ & $68(20.5)$ \\
\hline z17 & $\mathrm{v}$ & $\mathrm{v}$ & $\mathrm{v}$ & $\mathrm{v}$ & $11(3.3)$ & $9(2.7)$ & $20(3.0)$ \\
\hline Others $^{b}$ & $\cdots$ & $\cdots$ & $\cdots$ & $\cdots$ & $16(4.8)$ & $26(7.6)$ & $42(12.7)$ \\
\hline Diversity index ${ }^{c}$ & $\ldots$ & $\ldots$ & $\ldots$ & $\ldots$ & 0.78 & 0.87 & 0.86 \\
\hline
\end{tabular}

${ }^{a}$ Blast isolates were evaluated according to the reactions of DV groups, as classified by Hayashi and Fukuta (2009). v = virulent to DV or Lijiangxintuanheigu (LTH) and a $=$ avirulent to DV or LTH.

b Types z01, z03, z11, z12, z13, z14, and z15.

${ }^{c}$ Diversity index was calculated by using the method of Simpson (1949).

Table 4. Numbers of blast isolates of each reaction type, as categorized on the basis of the reactions of differential variety (DV) group k

\begin{tabular}{|c|c|c|c|c|c|c|c|c|c|c|}
\hline \multirow[b]{2}{*}{ Reaction type } & \multicolumn{7}{|c|}{ Rice resistance gene } & \multicolumn{3}{|c|}{$\begin{array}{c}\text { Number of virulent isolates }(\%) \text { per blast } \\
\text { isolate cluster group }\end{array}$} \\
\hline & $\overline{P i k-s}$ & Pik-m & Pil & $P i k-h$ & $P i k$ & Pik-p & $\overline{P i 7(t)}$ & $\mathbf{I}$ & II & Total \\
\hline $\mathrm{k} 000$ & $\mathrm{a}$ & $\mathrm{a}$ & $\mathrm{a}$ & $\mathrm{a}$ & $\mathrm{a}$ & $\mathrm{a}$ & $\mathrm{a}$ & $0(0.0)$ & $18(5.4)$ & $18(5.4)$ \\
\hline k100 & $\mathrm{v}$ & $\mathrm{a}$ & $\mathrm{a}$ & $\mathrm{a}$ & $\mathrm{a}$ & $\mathrm{a}$ & $\mathrm{a}$ & $0(0.0)$ & $93(28.1)$ & $93(28.1)$ \\
\hline k102 & $\mathrm{v}$ & $\mathrm{a}$ & $\mathrm{a}$ & $\mathrm{a}$ & $\mathrm{a}$ & $\mathrm{v}$ & $\mathrm{a}$ & $0(0.0)$ & $18(5.4)$ & $15(5.4)$ \\
\hline k177 & $\mathrm{v}$ & $\mathrm{v}$ & $\mathrm{v}$ & $\mathrm{v}$ & $\mathrm{v}$ & $\mathrm{v}$ & $\mathrm{v}$ & $138(41.7)$ & $0(0.0)$ & $138(41.7)$ \\
\hline Others ${ }^{b}$ & $\ldots$ & $\ldots$ & $\ldots$ & $\ldots$ & $\ldots$ & $\ldots$ & $\ldots$ & $30(9.1)$ & $34(10.3)$ & $64(19.3)$ \\
\hline Diversity index ${ }^{c}$ & $\ldots$ & $\ldots$ & $\ldots$ & $\ldots$ & $\ldots$ & $\ldots$ & $\ldots$ & 0.32 & 0.65 & 0.74 \\
\hline
\end{tabular}


the isolates of U43 (virulent to DV for Pit and Pia and to LTH) and U73 (virulent to DV for Pish, Pib, Pit, and Pia and to LTH) in group I were higher than those of group II. The frequencies of the isolates of reaction types U61 (virulent to DV for Pib and Pit and to LTH) and U63 (virulent to DV for Pib, Pit, and Pia and to LTH) in group II were higher than those in group I. These five reaction types mostly divided the isolates into two groups; the reactions of DV for Pib contributed to this classification. The diversity indexes of groups I and II and both groups combined were $0.78,0.59$, and 0.72 , respectively; the isolates in group I were more diversified than those in group II.

Eight reaction types (i0, i1, i2, i3, i4, i5, i6, and i7) were found in DV group i (Tables 2 through 6). The three major reaction types (i0, i4, and i7) included 121 (36.5\%), 35 (10.5\%), and 145 (43.8\%) blast isolates, respectively. The other five reaction types included only a few isolates. The frequency of group II in reaction type i0 was higher than that of group I; in contrast, in the case of reaction type i7, the frequency of group I was higher than that of group II. The major reaction types (i0 and i7) clearly divided the isolates into two groups. In other words, the set of virulence or avirulence genes for the DV for $\mathrm{Pii}$ and Pi3 contributed to the classification into groups I and II. The diversity indexes of groups I and II and both groups combined were $0.38,0.52$, and 0.66 , respectively.

In total, 32 reaction types (Tables 2 through 6) were found in DV group k. Four reaction types $(\mathrm{k} 000, \mathrm{k} 100, \mathrm{k} 102$, and k177) were dominant, and all blast isolates of $\mathrm{k} 000(n=18,5.4 \%), \mathrm{k} 100(n=$ $1893,28.1 \%)$, and $\mathrm{k} 102(n=1818,5.4 \%)$, were included in group II. In contrast, all isolates of $\mathrm{k} 177(n=18138,41.7 \%)$ were categorized into group I. The other reaction types in both clusters included only a few isolates. Blast isolates were classified into two groups on the basis of the different frequencies of the four main reaction types (k000, k100, k102, and k177). In other words, the pathogen genes virulent to the DV for Pik-m, Pil, Pik-h, Pik, and Pi7(t) were responsible for allocation of the isolates to two groups. The diversity indexes of groups I and II and both groups combined were 0.32 , 0.65 , and 0.74 , respectively. Thus, the isolates in group II were more diversified than those in group $\mathrm{I}$.

In DV group $\mathrm{z}$, blast isolates were classified into 15 reaction types (Tables 2 through 6). Seven reaction types (z00, z02, z04, z05, z06, z07, and z17) dominated. Two types (z00 and z02) had higher frequencies of blast isolates in group II than in group I. Types z06 and z07 had higher frequencies in group I than in group II. For the other reaction types, there were no marked differences in frequency between group I and II. These results suggested that blast genes virulent or avirulent to DV for Piz and Piz-t might be associated with the differentiation of isolates between groups I and II but, unlike in the case of the other reaction types, the contributions to this differentiation were unremarkable. The diversity indexes of groups I and II and both groups combined were $0.78,0.87$, and 0.86 respectively.

In total, 41 reaction types (Tables 2 through 6)were found in DV group ta. Reaction types ta003, ta023, ta402, ta403, ta423, and ta431 included most of the blast isolates. The other reaction types included only a few isolates. The numbers of reaction types in groups I and II were 28 and 32, respectively. The major reaction types (ta002, ta003, ta023, ta402, ta403, ta423, and ta431) were commonly distributed in both groups but the occurrence frequencies of ta003, ta023, ta402, and ta 423 were higher in group I. Type ta 403 was the most dominant reaction type $(31.1 \%)$ among the ta group and was commonly distributed in both groups I and II. There were no specific virulence or avirulence genes that contributed markedly to allocation of the blast isolates to the two groups. The diversity indexes of groups I and II and both groups combined were $0.90,0.80$, and 0.87 , respectively.

Using the designation systems proposed by Hayashi and Fukuta (2009), all of the blast isolates were categorized into 10, 8, 32, 15, and 41 reaction types of the five DV groups $\mathrm{U}, \mathrm{i}, \mathrm{k}, \mathrm{z}$, and ta, respectively. U03, U23, U43, U63, U73, i0, i4, i7, k000, k100, k102, k177, z00, z02, z04, z05, z06, z07, z17, ta003, ta023, ta402, ta403, ta423, and ta431 had high occurrence frequencies and were considered the major reaction types. Reaction types U03, U43, U61,U63, U73,i0, i7, $\mathrm{k} 000, \mathrm{k} 100, \mathrm{k} 102$, and $\mathrm{k} 177$ showed markedly different frequencies between the two isolate groups, and the reactions of the DV for Pib, Pii, Pi3, Pik-m, Pil, Pik-h, Pik, and Pi7(t) to blast isolates of these types indicated their contribution to the differentiation of groups I and II. The values of Simpson's diversity indexes of the pathogen isolates in DV groups $\mathrm{z}$ and ta were higher than those in the other three (groups U, i, and k).

Designation of race. The 331 tested blast isolates were categorized into 267 races on the basis of our analyses of the reaction types of the five DV groups (U, i, k, z, and ta). Blast race U63-i7-k177-z07ta423 in group I comprised nine isolates, and race U63-i0-k100-z00ta403 in group II comprised six isolates. Most of the other races consisted of single isolates.

Selection of standard differential blast isolates. On the basis of our evaluations using DV for 23 blast resistance genes and LTH, we proposed 25 representative standard differential blast isolates (Table 7). These blast isolates provoked specific reactions in the 25 DV and LTH. Between three and seven isolates that corresponded to the number of DV in each DV group $(\mathrm{U}, \mathrm{i}, \mathrm{k}, \mathrm{z}$, and ta) were selected. The sporulation abilities of these isolates were also high (50 to $544 \times 10^{4}$ spores $/ \mathrm{ml} /$ plate) on oatmeal agar plate under laboratory conditions. These isolates should be useful for genetic analysis of resistance in rice germplasm in Bangladesh.

\section{Discussion}

Based on the reaction patterns of 25 DV harboring 23 resistance genes (Fukuta et al. 2004; Kobayashi et al. 2007; TelebancoYanoria et al. 2010; Tsunematsu et al. 2000) and the susceptible check LTH, high virulence frequencies of blast isolates were found in eight DV (for Pia, Pib, Pit, Pik-s, Piz-t, Pi12(t), Pi19(t), and $P i 20(\mathrm{t}))$ and LTH. Low virulence frequencies were found in the DV for Pish, Pi9, Pita-2, and Pita (Fig. 2). These findings indicated

Table 6. Numbers of blast isolates of each reaction type, as categorized on the basis of the reactions of differential variety (DV) group ta

\begin{tabular}{|c|c|c|c|c|c|c|c|c|c|c|}
\hline \multirow[b]{2}{*}{ Type } & \multicolumn{7}{|c|}{ Rice resistance gene } & \multicolumn{3}{|c|}{$\begin{array}{c}\text { Number of virulent isolates (\%) per } \\
\text { blast isolate cluster group }{ }^{\mathbf{a}}\end{array}$} \\
\hline & Pita-2 (Re) & Pita-2 (Pi) & $\operatorname{Pi12}(\mathrm{t})$ & Pita (K1) & Pita (CP1) & $\operatorname{Pi19}(\mathrm{t})$ & $\operatorname{Pi20}(\mathrm{t})$ & $\mathbf{I}$ & II & Total \\
\hline ta003 & $\mathrm{a}$ & $\mathrm{a}$ & $\mathrm{a}$ & $\mathrm{a}$ & $\mathrm{a}$ & $\mathrm{v}$ & $\mathrm{v}$ & $21(6.3)$ & $2(0.6)$ & $23(6.9)$ \\
\hline ta023 & $\mathrm{a}$ & a & $\mathrm{a}$ & $\mathrm{a}$ & $\mathrm{v}$ & $\mathrm{v}$ & $\mathrm{v}$ & $11(3.3)$ & $1(0.3)$ & $12(3.6)$ \\
\hline ta402 & $\mathrm{a}$ & $\mathrm{a}$ & $\mathrm{v}$ & $\mathrm{a}$ & $\mathrm{a}$ & $\mathrm{a}$ & $\mathrm{v}$ & $15(4.5)$ & $8(2.4)$ & $23(6.9)$ \\
\hline ta403 & $\mathrm{a}$ & $\mathrm{a}$ & $\mathrm{v}$ & $\mathrm{a}$ & $\mathrm{a}$ & $\mathrm{v}$ & $\mathrm{v}$ & $34(10.2)$ & $69(20.9)$ & $103(31.1)$ \\
\hline ta423 & $\mathrm{a}$ & a & $\mathrm{v}$ & $\mathrm{a}$ & $\mathrm{v}$ & $\mathrm{v}$ & $\mathrm{v}$ & $24(7.2)$ & $10(3.0)$ & $34(10.2)$ \\
\hline ta431 & $\mathrm{a}$ & $\mathrm{a}$ & $\mathrm{v}$ & $\mathrm{v}$ & $\mathrm{v}$ & $\mathrm{v}$ & $\mathrm{a}$ & $12(3.6)$ & $15(4.5)$ & $27(8.1)$ \\
\hline Others ${ }^{b}$ & $\ldots$ & $\ldots$ & $\ldots$ & $\ldots$ & $\ldots$ & $\ldots$ & $\ldots$ & $51(15.4)$ & $58(17.5)$ & $109(32.9)$ \\
\hline $\mathrm{DI}^{\mathrm{c}}$ & $\ldots$ & $\ldots$ & $\ldots$ & $\ldots$ & $\ldots$ & $\ldots$ & $\ldots$ & 0.90 & 0.80 & 0.87 \\
\hline
\end{tabular}

${ }^{a}$ Blast isolates were evaluated according to the reactions of DV groups, as classified by Hayashi and Fukuta (2009). v = virulent to DV or Lijiangxintuanheigu $(\mathrm{LTH})$ and $\mathrm{a}=$ avirulent to DV or LTH.

b Types ta000, ta002, ta020, ta021, ta022, ta031, ta033, ta123, ta203, ta223, ta400, ta401, ta412, ta413, ta420, ta421, ta422, ta432, ta433, ta503, ta503, ta523, ta531, ta533, ta602, ta603, ta613, ta622, ta623, ta631, ta633, ta723, ta732, and ta733.

c Diversity index (DI) was calculated by using the method of Simpson (1949). 
that virulent pathogen genes against the resistance genes Pia, Pib, Pit, Pik-s, Piz-t, Pi12(t), Pi19(t), and Pi2O(t), and genes avirulent for Pish, Pi9, Pita-2, and Pita, were distributed widely in Bangladesh. To our knowledge, this is the first information to be published on blast pathogen distribution in Bangladesh.

The isolates were classified into two cluster groups (I and II) based on the reaction pattern (Fig. 2; Table 1). Reaction types U63, z04, and ta403 were often found at high frequencies in both groups. Consequently, these three reaction types were dominant, and distributed together in Bangladesh. Eleven reaction types corresponding to Pib,
Pii, Pi3, Pik-m, Pil, Pik-h, Pik, and Pi7(t) genes showed markedly different frequencies between groups I and II. Thus, the reactions of these blast isolates contributed to differentiation of the two groups. The diversity indexes calculated by using the method of Simpson (1949) of DV groups z and ta were higher than those in the other three (groups $\mathrm{U}, \mathrm{i}$, and $\mathrm{k}$ ), and this difference was related to differentiation of the two groups. Thus, the diversity of the blast isolate virulence genes that contributed to differentiation of the cluster groups was lower than that of the noncontributing genes (Tables 2 through 6). In other words, blast pathogens in Bangladesh were differentiated

Table 7. Selection of standard differential blast isolates from Bangladesh

\begin{tabular}{|c|c|c|c|c|c|c|c|c|c|c|c|c|c|}
\hline \multirow[b]{4}{*}{ Sample } & \multirow[b]{4}{*}{ Race name } & \multicolumn{12}{|c|}{ Reaction to DV and $\mathrm{LTH}^{\mathrm{a}}$} \\
\hline & & \multicolumn{5}{|c|}{$\mathbf{U}$} & \multicolumn{3}{|c|}{$\mathbf{i}$} & \multicolumn{4}{|c|}{$\mathbf{k}$} \\
\hline & & LTH & $\begin{array}{l}\text { IRBLa- } \\
\text { A }\end{array}$ & $\begin{array}{l}\text { IRBLsh- } \\
\text { B }\end{array}$ & $\begin{array}{l}\text { IRBLb- } \\
\text { B }\end{array}$ & $\begin{array}{l}\text { IRBLt- } \\
\text { K59 }\end{array}$ & $\begin{array}{l}\text { IRBLi- } \\
\text { F5 }\end{array}$ & $\begin{array}{l}\text { IRBL3- } \\
\text { CP4 }\end{array}$ & $\begin{array}{l}\text { IRBL5- } \\
\quad M\end{array}$ & $\begin{array}{l}\text { IRBLks- } \\
\text { F5 }\end{array}$ & $\begin{array}{l}\text { IRBLkm- } \\
\text { Ts }\end{array}$ & $\begin{array}{l}\text { IRBL1- } \\
\text { CL }\end{array}$ & $\begin{array}{l}\text { IRBLkh- } \\
\text { K3[LT] }\end{array}$ \\
\hline & & - & Pia & Pish & $P i b$ & Pit & $P i i$ & Pi3 & $P i 5(t)$ & Pik-s & Pik-m & Pil & Pik-h \\
\hline $\mathrm{Ba} 57$ & $\begin{array}{l}\text { U61-i4-k100-z04- } \\
\text { ta403 }\end{array}$ & $\mathrm{v}$ & a & a & $\mathrm{v}$ & $\mathrm{v}$ & a & a & $\mathrm{v}$ & $\mathrm{v}$ & a & a & a \\
\hline $\begin{array}{l}\text { BD346- } \\
\text { 3p }\end{array}$ & $\begin{array}{l}\text { U63-i7-k177-z07- } \\
\text { ta733 }\end{array}$ & $\mathrm{v}$ & $\mathrm{v}$ & a & $\mathrm{v}$ & $\mathrm{v}$ & $\mathrm{v}$ & $\mathrm{v}$ & $\mathrm{v}$ & $\mathrm{v}$ & $\mathrm{v}$ & $\mathrm{v}$ & $\mathrm{v}$ \\
\hline $1186 a$ & $\begin{array}{l}\text { U43-i7-k177-z06- } \\
\text { ta023 }\end{array}$ & $\mathrm{v}$ & $\mathrm{v}$ & a & a & $\mathrm{v}$ & $\mathrm{v}$ & $\mathrm{v}$ & $\mathrm{v}$ & $\mathrm{v}$ & $\mathrm{v}$ & $\mathrm{v}$ & $\mathrm{v}$ \\
\hline BD576p & $\begin{array}{l}\text { U23-i7-k177-z06- } \\
\text { ta423 }\end{array}$ & $\mathrm{v}$ & $\mathrm{v}$ & $\mathrm{a}$ & $\mathrm{v}$ & a & $\mathrm{v}$ & $\mathrm{v}$ & $\mathrm{v}$ & $\mathrm{v}$ & $\mathrm{v}$ & $\mathrm{v}$ & $\mathrm{v}$ \\
\hline $\mathrm{Ba77}(\mathrm{a})$ & $\begin{array}{l}\text { U73-i6-k177-z05- } \\
\text { ta403 }\end{array}$ & $\mathrm{v}$ & $\mathrm{v}$ & $\mathrm{v}$ & $\mathrm{v}$ & $\mathrm{v}$ & a & $\mathrm{v}$ & $\mathrm{v}$ & $\mathrm{v}$ & $\mathrm{v}$ & $\mathrm{v}$ & $\mathrm{v}$ \\
\hline BD577p & $\begin{array}{l}\text { U73-i4-k177-z17- } \\
\text { ta403 }\end{array}$ & $\mathrm{v}$ & $\mathrm{v}$ & $\mathrm{v}$ & $\mathrm{v}$ & $\mathrm{v}$ & a & a & $\mathrm{v}$ & $\mathrm{v}$ & $\mathrm{v}$ & $\mathrm{v}$ & $\mathrm{v}$ \\
\hline $\mathrm{Ba} 45 \mathrm{~b}$ & $\begin{array}{l}\text { U63-i3-k177-z07- } \\
\text { ta402 }\end{array}$ & $\mathrm{v}$ & $\mathrm{v}$ & a & $\mathrm{v}$ & $\mathrm{v}$ & $\mathrm{v}$ & $\mathrm{v}$ & $\mathrm{a}$ & $\mathrm{v}$ & $\mathrm{v}$ & $\mathrm{v}$ & $\mathrm{v}$ \\
\hline Ba145a & $\begin{array}{l}\text { U63-i7-k047-z05- } \\
\text { ta431 }\end{array}$ & $\mathrm{v}$ & $\mathrm{v}$ & $\mathrm{a}$ & $\mathrm{v}$ & $\mathrm{v}$ & $\mathrm{v}$ & $\mathrm{v}$ & $\mathrm{v}$ & a & $\mathrm{a}$ & $\mathrm{a}$ & $\mathrm{v}$ \\
\hline Ba106 & $\begin{array}{l}\text { U73-i7-k100-z17- } \\
\text { ta431 }\end{array}$ & $\mathrm{v}$ & $\mathrm{v}$ & $\mathrm{v}$ & $\mathrm{v}$ & $\mathrm{v}$ & $\mathrm{v}$ & $\mathrm{v}$ & $\mathrm{v}$ & $\mathrm{v}$ & a & a & $\mathrm{a}$ \\
\hline 1149 & $\begin{array}{l}\text { U63-i7-k157-z07- } \\
\text { ta403 }\end{array}$ & $\mathrm{v}$ & $\mathrm{v}$ & $\mathrm{a}$ & $\mathrm{v}$ & $\mathrm{v}$ & $\mathrm{v}$ & $\mathrm{v}$ & $\mathrm{v}$ & $\mathrm{v}$ & $\mathrm{v}$ & $\mathrm{a}$ & $\mathrm{v}$ \\
\hline Ba88p & $\begin{array}{l}\text { U73-i4-k137-z17- } \\
\text { ta433 }\end{array}$ & $\mathrm{v}$ & $\mathrm{v}$ & $\mathrm{v}$ & $\mathrm{v}$ & $\mathrm{v}$ & $\mathrm{a}$ & $\mathrm{a}$ & $\mathrm{v}$ & $\mathrm{v}$ & $\mathrm{v}$ & $\mathrm{v}$ & $\mathrm{a}$ \\
\hline Ba52p & $\begin{array}{l}\text { U73-i4-k136-z16- } \\
\text { ta431 }\end{array}$ & $\mathrm{v}$ & $\mathrm{v}$ & $\mathrm{v}$ & $\mathrm{v}$ & $\mathrm{v}$ & a & a & $\mathrm{v}$ & $\mathrm{v}$ & $\mathrm{v}$ & $\mathrm{v}$ & a \\
\hline 1075 & $\begin{array}{l}\text { U73-i4-k171-z17- } \\
\text { ta433 }\end{array}$ & $\mathrm{v}$ & $\mathrm{v}$ & $\mathrm{v}$ & $\mathrm{v}$ & $\mathrm{v}$ & a & a & $\mathrm{v}$ & $\mathrm{v}$ & $\mathrm{v}$ & $\mathrm{v}$ & $\mathrm{v}$ \\
\hline $\begin{array}{l}\text { Ba760- } \\
3(\mathrm{~b})\end{array}$ & $\begin{array}{l}\text { U23-i7-k173-z06- } \\
\text { ta431 }\end{array}$ & $\mathrm{v}$ & $\mathrm{v}$ & a & $\mathrm{v}$ & a & $\mathrm{v}$ & $\mathrm{v}$ & $\mathrm{v}$ & $\mathrm{v}$ & $\mathrm{v}$ & $\mathrm{v}$ & $\mathrm{v}$ \\
\hline $1189 \mathrm{~b}$ & $\begin{array}{l}\text { U73-i7-k177-z07- } \\
\text { ta733 }\end{array}$ & $\mathrm{v}$ & $\mathrm{v}$ & $\mathrm{v}$ & $\mathrm{v}$ & $\mathrm{v}$ & $\mathrm{v}$ & $\mathrm{v}$ & $\mathrm{v}$ & $\mathrm{v}$ & $\mathrm{v}$ & $\mathrm{v}$ & $\mathrm{v}$ \\
\hline 962 & $\begin{array}{l}\text { U03-i7-k177-z06- } \\
\text { ta002 }\end{array}$ & $\mathrm{v}$ & $\mathrm{v}$ & $\mathrm{a}$ & $\mathrm{a}$ & a & $\mathrm{v}$ & $\mathrm{v}$ & $\mathrm{v}$ & $\mathrm{v}$ & $\mathrm{v}$ & $\mathrm{v}$ & $\mathrm{v}$ \\
\hline BD634p & $\begin{array}{l}\text { U73-i7-k177-z15- } \\
\text { ta423 }\end{array}$ & $\mathrm{v}$ & $\mathrm{v}$ & $\mathrm{v}$ & $\mathrm{v}$ & $\mathrm{v}$ & $\mathrm{v}$ & $\mathrm{v}$ & $\mathrm{v}$ & $\mathrm{v}$ & $\mathrm{v}$ & $\mathrm{v}$ & $\mathrm{v}$ \\
\hline Ba196a & $\begin{array}{l}\text { U73-i4-k102-z13- } \\
\text { ta723 }\end{array}$ & $\mathrm{v}$ & $\mathrm{v}$ & $\mathrm{v}$ & $\mathrm{v}$ & $\mathrm{v}$ & a & a & $\mathrm{v}$ & $\mathrm{v}$ & a & $\mathrm{a}$ & a \\
\hline 1092 & $\begin{array}{l}\text { U43-i7-k177-z06- } \\
\text { ta403 }\end{array}$ & $\mathrm{v}$ & $\mathrm{v}$ & $\mathrm{a}$ & $\mathrm{a}$ & $\mathrm{v}$ & $\mathrm{v}$ & $\mathrm{v}$ & $\mathrm{v}$ & $\mathrm{v}$ & $\mathrm{v}$ & $\mathrm{v}$ & $\mathrm{v}$ \\
\hline BD642p & $\begin{array}{l}\text { U73-i7-k177-z17- } \\
\text { ta403 }\end{array}$ & $\mathrm{v}$ & $\mathrm{v}$ & $\mathrm{v}$ & $\mathrm{v}$ & $\mathrm{v}$ & $\mathrm{v}$ & $\mathrm{v}$ & $\mathrm{v}$ & $\mathrm{v}$ & $\mathrm{v}$ & $\mathrm{v}$ & $\mathrm{v}$ \\
\hline Ba46(a) & $\begin{array}{l}\text { U63-i7-k177-z17- } \\
\text { ta023 }\end{array}$ & $\mathrm{v}$ & $\mathrm{v}$ & $\mathrm{a}$ & $\mathrm{v}$ & $\mathrm{v}$ & $\mathrm{v}$ & $\mathrm{v}$ & $\mathrm{v}$ & $\mathrm{v}$ & $\mathrm{v}$ & $\mathrm{v}$ & $\mathrm{v}$ \\
\hline Ba201a & $\begin{array}{l}\text { U63-i4-k177-z00- } \\
\text { ta603 }\end{array}$ & $\mathrm{v}$ & $\mathrm{v}$ & $\mathrm{a}$ & $\mathrm{v}$ & $\mathrm{v}$ & a & a & $\mathrm{v}$ & $\mathrm{v}$ & $\mathrm{v}$ & $\mathrm{v}$ & $\mathrm{v}$ \\
\hline BD578p & $\begin{array}{l}\text { U73-i7-k177-z16- } \\
\text { ta402 }\end{array}$ & $\mathrm{v}$ & $\mathrm{v}$ & $\mathrm{v}$ & $\mathrm{v}$ & $\mathrm{v}$ & $\mathrm{v}$ & $\mathrm{v}$ & $\mathrm{v}$ & $\mathrm{v}$ & $\mathrm{v}$ & $\mathrm{v}$ & $\mathrm{v}$ \\
\hline $\mathrm{Ba} 41 \mathrm{~b}$ & $\begin{array}{l}\text { U73-i7-k177-z17- } \\
\text { ta402 }\end{array}$ & $\mathrm{v}$ & $\mathrm{v}$ & v & $\mathrm{v}$ & $\mathrm{v}$ & $\mathrm{v}$ & $\mathrm{v}$ & $\mathrm{v}$ & $\mathrm{v}$ & $\mathrm{v}$ & $\mathrm{v}$ & $\mathrm{v}$ \\
\hline Ba87p & $\begin{array}{l}\text { U73-i7-k177-z17- } \\
\text { ta431 }\end{array}$ & $\mathrm{v}$ & $\mathrm{v}$ & $\mathrm{v}$ & $\mathrm{v}$ & $\mathrm{v}$ & $\mathrm{v}$ & $\mathrm{v}$ & $\mathrm{v}$ & $\mathrm{v}$ & $\mathrm{v}$ & $\mathrm{v}$ & $\mathrm{v}$ \\
\hline
\end{tabular}

\footnotetext{
${ }^{a}$ Each pathogen was designated by using the method of Hayashi and Fukuta (2009). v = virulent to differential variety (DV) or Lijiangxintuanheigu (LTH) and
} $\mathrm{a}=$ avirulent to DV or LTH. 
mainly by their behavior against the resistance genes in DV groups $\mathrm{U}, \mathrm{i}$, and $\mathrm{k}$, and the genetic diversity of the blast isolate virulence genes that contributed to the differentiation of pathogen groups I and II was lower than that of the genes that did not contribute.

Blast isolates from different regions in Bangladesh did not differ markedly from each other in terms of their virulence to DV (Fig. 3 ). In contrast, isolates from rainfed lowlands were classified mostly into group I, whereas those from irrigated lowlands were classified into group II (Table 1). These results indicated that the virulence spectra of the blast isolates in groups I and II differed in terms of the reactions of the DV for Pib, Pii, Pi3, Pik-m, Pil, Pik-h, Pik, and $P i 7(\mathrm{t})$ and between ecosystems for rice cultivation. Bangladesh's cultivable rice land is mostly floodplain. Irrigated and rainfed lowland rice is usually cultivated in the same region, and rice-growing ecosystems are closely associated with seasonal and varietal rice aspects. As a result, isolates from both irrigated and rainfed lowland ecosystems were collected from the same region. However, differences in the cluster groups were found between ecosystems. Thus, the dominant blast races changed dramatically between seasons or ecosystems in the same regions of Bangladesh. In Bangladesh, the

Table 7. (continued from preceding page)

\begin{tabular}{|c|c|c|c|c|c|c|c|c|c|c|c|c|c|}
\hline \multicolumn{14}{|c|}{ Reaction to DV and $\mathrm{LTH}^{\mathrm{a}}$} \\
\hline \multirow{2}{*}{$\begin{array}{c}\frac{k}{\text { IRBLk- }} \\
\text { Ka[LT] }\end{array}$} & \multicolumn{6}{|c|}{$\mathbf{z}$} & \multicolumn{7}{|c|}{ ta } \\
\hline & $\begin{array}{c}\text { IRBLkp- } \\
\text { K60 }\end{array}$ & $\begin{array}{c}\text { IRBL7- } \\
\mathbf{M}\end{array}$ & $\begin{array}{c}\text { IRBL9- } \\
\text { W }\end{array}$ & $\begin{array}{c}\text { IRBLz- } \\
\text { Fu }\end{array}$ & $\begin{array}{c}\text { IRBLz5- } \\
\text { CA-1 }\end{array}$ & $\begin{array}{c}\text { IRBLzt- } \\
\mathbf{T}\end{array}$ & $\begin{array}{c}\text { IRBLta2- } \\
\text { Pi }\end{array}$ & $\begin{array}{c}\text { IRBLta2- } \\
\operatorname{Re}\end{array}$ & $\begin{array}{c}\text { IRBL12- } \\
\mathrm{M}\end{array}$ & $\begin{array}{l}\text { IRBLta- } \\
\text { K1 }\end{array}$ & $\begin{array}{c}\text { IRBLta- } \\
\text { CP1 }\end{array}$ & $\begin{array}{c}\text { IRBL19- } \\
\text { A }\end{array}$ & $\begin{array}{l}\text { IRBL20- } \\
\text { IR24 }\end{array}$ \\
\hline Pik & Pik-p & $P i 7(t)$ & $\operatorname{Pi9}(\mathrm{t})$ & $\mathrm{Piz}$ & Piz-5 & Piz- $t$ & Pita-2 & Pita-2 & $\operatorname{Pi12}(\mathrm{t})$ & pita & pita & $\operatorname{Pi19}(t)$ & $\operatorname{Pi20}(t)$ \\
\hline $\mathrm{a}$ & $\mathrm{a}$ & $\mathrm{a}$ & $\mathrm{a}$ & $\mathrm{a}$ & a & $\mathrm{v}$ & a & $\mathrm{a}$ & $\mathrm{v}$ & $\mathrm{a}$ & $\mathrm{a}$ & $\mathrm{v}$ & $\mathrm{v}$ \\
\hline $\mathrm{v}$ & $\mathrm{v}$ & $\mathrm{v}$ & $\mathrm{a}$ & $\mathrm{v}$ & $\mathrm{v}$ & $\mathrm{v}$ & $\mathrm{v}$ & $\mathrm{v}$ & $\mathrm{v}$ & $\mathrm{v}$ & $\mathrm{v}$ & $\mathrm{v}$ & $\mathrm{v}$ \\
\hline $\mathrm{v}$ & $\mathrm{v}$ & $\mathrm{v}$ & $\mathrm{a}$ & $\mathrm{a}$ & $\mathrm{v}$ & $\mathrm{v}$ & $\mathrm{a}$ & $\mathrm{a}$ & $\mathrm{a}$ & $\mathrm{a}$ & $\mathrm{v}$ & $\mathrm{v}$ & $\mathrm{v}$ \\
\hline $\mathrm{v}$ & $\mathrm{v}$ & $\mathrm{v}$ & $\mathrm{a}$ & $\mathrm{a}$ & $\mathrm{v}$ & $\mathrm{v}$ & $\mathrm{a}$ & $\mathrm{a}$ & $\mathrm{v}$ & $\mathrm{a}$ & $\mathrm{v}$ & $\mathrm{v}$ & $\mathrm{v}$ \\
\hline $\mathrm{v}$ & $\mathrm{v}$ & $\mathrm{v}$ & $\mathrm{a}$ & $\mathrm{v}$ & $\mathrm{a}$ & $\mathrm{v}$ & $\mathrm{a}$ & $\mathrm{a}$ & $\mathrm{v}$ & $\mathrm{a}$ & $\mathrm{a}$ & $\mathrm{v}$ & $\mathrm{v}$ \\
\hline $\mathrm{v}$ & $\mathrm{v}$ & $\mathrm{v}$ & $\mathrm{v}$ & $\mathrm{v}$ & $\mathrm{v}$ & $\mathrm{v}$ & $\mathrm{a}$ & $\mathrm{a}$ & $\mathrm{v}$ & $\mathrm{a}$ & $\mathrm{a}$ & $\mathrm{v}$ & $\mathrm{v}$ \\
\hline $\mathrm{v}$ & $\mathrm{v}$ & $\mathrm{v}$ & $\mathrm{a}$ & $\mathrm{v}$ & $\mathrm{v}$ & $\mathrm{v}$ & a & $\mathrm{a}$ & $\mathrm{v}$ & $\mathrm{a}$ & $\mathrm{a}$ & $\mathrm{a}$ & $\mathrm{v}$ \\
\hline $\mathrm{v}$ & $\mathrm{v}$ & $\mathrm{v}$ & $\mathrm{a}$ & $\mathrm{v}$ & $\mathrm{a}$ & $\mathrm{v}$ & $\mathrm{a}$ & $\mathrm{a}$ & $\mathrm{v}$ & $\mathrm{v}$ & $\mathrm{v}$ & $\mathrm{v}$ & a \\
\hline $\mathrm{a}$ & $\mathrm{a}$ & $\mathrm{a}$ & $\mathrm{v}$ & $\mathrm{v}$ & $\mathrm{v}$ & $\mathrm{v}$ & $\mathrm{a}$ & $\mathrm{a}$ & $\mathrm{v}$ & $\mathrm{v}$ & $\mathrm{v}$ & $\mathrm{v}$ & $\mathrm{a}$ \\
\hline $\mathrm{v}$ & $\mathrm{v}$ & $\mathrm{v}$ & a & $\mathrm{v}$ & $\mathrm{v}$ & $\mathrm{v}$ & a & a & $\mathrm{v}$ & a & a & $\mathrm{v}$ & $\mathrm{v}$ \\
\hline $\mathrm{v}$ & $\mathrm{v}$ & $\mathrm{v}$ & $\mathrm{v}$ & $\mathrm{v}$ & $\mathrm{v}$ & $\mathrm{v}$ & a & a & $\mathrm{v}$ & $\mathrm{v}$ & $\mathrm{v}$ & $\mathrm{v}$ & $\mathrm{v}$ \\
\hline $\mathrm{a}$ & $\mathrm{v}$ & $\mathrm{v}$ & $\mathrm{v}$ & $\mathrm{a}$ & $\mathrm{v}$ & $\mathrm{v}$ & $\mathrm{a}$ & $\mathrm{a}$ & $\mathrm{v}$ & $\mathrm{v}$ & $\mathrm{v}$ & $\mathrm{v}$ & $\mathrm{a}$ \\
\hline $\mathrm{v}$ & $\mathrm{a}$ & $\mathrm{a}$ & $\mathrm{v}$ & $\mathrm{v}$ & $\mathrm{v}$ & $\mathrm{v}$ & a & $\mathrm{a}$ & $\mathrm{v}$ & $\mathrm{v}$ & $\mathrm{v}$ & $\mathrm{v}$ & $\mathrm{v}$ \\
\hline $\mathrm{v}$ & $\mathrm{v}$ & $\mathrm{a}$ & $\mathrm{a}$ & a & $\mathrm{v}$ & $\mathrm{v}$ & $\mathrm{a}$ & $\mathrm{a}$ & $\mathrm{v}$ & $\mathrm{v}$ & $\mathrm{v}$ & $\mathrm{v}$ & $\mathrm{a}$ \\
\hline $\mathrm{v}$ & $\mathrm{v}$ & $\mathrm{v}$ & $\mathrm{a}$ & $\mathrm{v}$ & $\mathrm{v}$ & $\mathrm{v}$ & $\mathrm{v}$ & $\mathrm{v}$ & $\mathrm{v}$ & $\mathrm{v}$ & $\mathrm{v}$ & $\mathrm{v}$ & $\mathrm{v}$ \\
\hline $\mathrm{v}$ & $\mathrm{v}$ & $\mathrm{v}$ & $\mathrm{a}$ & $\mathrm{a}$ & $\mathrm{v}$ & $\mathrm{v}$ & a & a & a & a & a & a & $\mathrm{v}$ \\
\hline $\mathrm{v}$ & $\mathrm{v}$ & $\mathrm{v}$ & $\mathrm{v}$ & $\mathrm{v}$ & $\mathrm{a}$ & $\mathrm{v}$ & $\mathrm{a}$ & $\mathrm{a}$ & $\mathrm{v}$ & $\mathrm{a}$ & $\mathrm{v}$ & $\mathrm{v}$ & $\mathrm{v}$ \\
\hline a & $\mathrm{v}$ & $\mathrm{a}$ & $\mathrm{v}$ & $\mathrm{v}$ & $\mathrm{v}$ & $\mathrm{a}$ & $\mathrm{v}$ & $\mathrm{v}$ & $\mathrm{v}$ & $\mathrm{a}$ & $\mathrm{v}$ & $\mathrm{v}$ & $\mathrm{v}$ \\
\hline $\mathrm{v}$ & $\mathrm{v}$ & $\mathrm{v}$ & $\mathrm{a}$ & $\mathrm{v}$ & $\mathrm{v}$ & $\mathrm{V}$ & $\mathrm{a}$ & $\mathrm{a}$ & $\mathrm{v}$ & $\mathrm{a}$ & $\mathrm{a}$ & $\mathrm{v}$ & $\mathrm{v}$ \\
\hline $\mathrm{v}$ & $\mathrm{v}$ & $\mathrm{v}$ & $\mathrm{v}$ & $\mathrm{v}$ & $\mathrm{v}$ & $\mathrm{v}$ & $\mathrm{a}$ & $\mathrm{a}$ & $\mathrm{v}$ & $\mathrm{a}$ & $\mathrm{a}$ & $\mathrm{v}$ & $\mathrm{v}$ \\
\hline $\mathrm{v}$ & $\mathrm{v}$ & $\mathrm{V}$ & $\mathrm{v}$ & $\mathrm{v}$ & $\mathrm{v}$ & $\mathrm{v}$ & $\mathrm{a}$ & $\mathrm{a}$ & $\mathrm{a}$ & $\mathrm{a}$ & $\mathrm{v}$ & $\mathrm{v}$ & $\mathrm{V}$ \\
\hline $\mathrm{v}$ & $\mathrm{v}$ & $\mathrm{v}$ & $\mathrm{a}$ & $\mathrm{a}$ & $\mathrm{a}$ & $\mathrm{a}$ & $\mathrm{a}$ & $\mathrm{v}$ & $\mathrm{V}$ & $\mathrm{a}$ & $\mathrm{a}$ & $\mathrm{v}$ & $\mathrm{V}$ \\
\hline $\mathrm{v}$ & $\mathrm{v}$ & $\mathrm{v}$ & $\mathrm{v}$ & a & $\mathrm{v}$ & $\mathrm{v}$ & a & a & $\mathrm{v}$ & a & a & a & $\mathrm{v}$ \\
\hline $\mathrm{v}$ & $\mathrm{v}$ & $\mathrm{v}$ & $\mathrm{v}$ & $\mathrm{v}$ & $\mathrm{v}$ & $\mathrm{V}$ & $\mathrm{a}$ & $\mathrm{a}$ & $\mathrm{v}$ & $\mathrm{a}$ & $\mathrm{a}$ & $\mathrm{a}$ & $\mathrm{v}$ \\
\hline $\mathrm{v}$ & $\mathrm{v}$ & $\mathrm{v}$ & $\mathrm{v}$ & $\mathrm{v}$ & $\mathrm{v}$ & $\mathrm{v}$ & $\mathrm{a}$ & $\mathrm{a}$ & $\mathrm{v}$ & $\mathrm{v}$ & $\mathrm{v}$ & $\mathrm{v}$ & $\mathrm{a}$ \\
\hline
\end{tabular}


rice-growing environment has been classified into five categoriesirrigated lowland, rainfed lowland, deepwater, tidal wetland, and rainfed upland - on the basis of physiography and land types (Khush 1984). Thus, all rice cultivars grown in the country are grouped into five distinct ecotypes with specific genetic backgrounds. In general, all the rice cultivars used in rainfed lowland ecosystems are moderately to strongly photosensitive, and all cultivars used in irrigated lowland ecosystems are relatively insensitive to photoperiod (Khush 1997). Disease resistance caused by incompatible combinations between host resistance gene and avirulent pathogen gene is usually governed by the gene-for-gene theory (Flor 1971; Silué et al. 1992). Araújo et al. (2005) reported that blast race composition varies mostly among cultivars. The structure of a pathogen population is likely to be strongly influenced by the structure of its host population (Chen et al. 1995). Host genotype has been shown clearly to exert strong selection pressure on the blast pathogen (Chen et al. 1995; Correa-Victoria and Zeigler 1993; Xia et al. 1993, 2000; Zeigler et al. 1994). Different resistance genes present in the host would be expected to exert selection on the pathogen population, resulting in differential compatibility between cultivars and the blast pathogen (Prabhu et al. 2002). The major varietal differentiation between the two rice-growing ecosystems (rainfed and irrigated lowland) in Bangladesh presumably influences the differentiation of blast isolates into two distinct groups. The relationship between blast isolate pathogenicity and resistance of rice cultivars will need to be clarified in each of Bangladesh's ecosystems.

Using the blast isolate designation system proposed by Hayashi and Fukuta (2009), we classified the 331 tested blast isolates into 267 races on the basis of the reaction types of five DV groups (U, i, k, z, and ta). Noda et al. (1999) identified 12 kinds of blast races among 129 isolates from Vietnam by using Japanese DV carrying 12 resistance genes (namely, Pia, Pik-s, Pii, Pik, Pik-m, Piz, Pita, Pita-2, Piz-t, Pik-p, Pib, and Pit). In Thailand, 175 races were identified from an investigation of 527 isolates by using 10 CO39 NIL carrying the resistance genes $P i 1, P i l(\mathrm{t})^{\mathrm{LAC}}, P i 1(\mathrm{t})^{\mathrm{TTP}}, P i z-5, P i 3$, $P i 4^{a}(\mathrm{t}), P i 4^{a}(\mathrm{t})^{\mathrm{PKT}}, P i 4^{a}(\mathrm{t})^{\mathrm{TTP}}, P i 4^{b}(\mathrm{t})$, and $P i a$, as well as LTH NIL carrying the resistance genes Pik-m, Pita, Pita-2, Pib, Pik-p, and $P i k$ (Mekwatanakarn et al. 2000). Many kinds of blast races have similarly been found in Bhutan (53 races out of 110 isolates), China (344 races out of 792 isolates), and the Philippines (70 races out of 119 isolates) and, in each case, few isolates have been classified into each race (Chen et al. 2001, Telebanco-Yanoria et al. 2008; Thinlay et al. 2000; Zeigler et al. 1995). No dominant blast races have been found in these previous studies. Although it is difficult to compare our data with those of previous studies because of variations in the numbers and kinds of resistance genes and in the genetic backgrounds of DV, our finding of many races agreed with those of these previous studies. By using the same DV set of monogenic lines (Fukuta et al. 2004; Kobayashi et al. 2007; Tsunematsu et al. 2000) and LTH NIL (Telebanco-Yanoria et al. 2010), as well as the designation system of Hayashi and Fukuta (2009), Fukuta et al. (2014) found 92 races among 122 blast isolates in Cambodia, Odjo et al. (2014) found 79 races among 96 isolates in West Africa, and Kawasaki-Tanaka et al. (2016) found 123 races among 310 blast isolates in Japan. Thus, highly diverse blast races are distributed in Bangladesh, as is the case in the tropical and temperate countries of Asia and Africa.

Here, for the first time, we outlined the diversity and differentiation of blast races in Bangladesh by using monogenic lines and NIL of LTH as DV (Fukuta et al. 2004; Kobayashi et al. 2007; Telebanco-Yanoria et al. 2010; Tsunematsu et al. 2000), plus a new designation system (Hayashi and Fukuta 2009). This information will help in the preliminary selection of standard differential blast isolates as the first step in the development of differential systems for Bangladesh (Table 7). Further study is needed to confirm the differentiation abilities of the selected isolates; moreover, additional isolates from nonrepresentative areas and ecosystems need to be investigated for further clarification. Thanks to the development and application of this differential system, our knowledge of the pathogenicity of blast isolates and the genotypes of resistance genes in rice cultivars will be applicable to breeding and pathological studies. The resulting information could be used to develop a durable system of protection against this disease in Bangladesh.

\section{Acknowledgments}

This study was part of a collaborative research project between the Bangladesh Rice Research Institute (BRRI) and the Japan International Research Center for Agricultural Sciences (JIRCAS) on "Blast Research Network for Stable Rice Production" from 2006 to 2010. It was also part of "Rice Innovation for Environmentally Sustainable Production Systems" from 2011 to 2015, funded by the Ministry of Agriculture, Forestry, and Fisheries of Japan. We thank the Japan Society for the Promotion of Science for providing a Post-Doctoral Fellowship to M. A. I. Khan (the first author of this article) for his involvement in this study, and JIRCAS for hosting him; and the Plant Pathology Division of BRRI for their help in collecting blast-infected samples from all over the Bangladesh.

\section{Literature Cited}

Ahmed, H. U., Haque, M. A., Shahjahan, A. K. M., and Miah, S. A. 1985. Blast resistance in rice germplasm in Bangladesh. Bangladesh J. Plant Pathol. 1:73-74.

Araújo, L. G., Prabhu, A. S., and da Silva, B. 2005. Virulence pattern of Pyricularia grisea isolates from farmer's fields on newly released upland rice cultivars. Fitopatol. Bras. 30:623-628.

Atkins, J. G., Robert, A. L., Adair, C. R., Goto, K., Kozaka, T., Yanagida, R., Yamada, M., and Matsumoto, S. 1967. An international set of rice cultivars for differentiating races of Pyricularia oryzae. Phytopathology 57:297-301.

Bonman, J. M. 1992a. Blast. Pages 14-17 in: Compendium of Rice Diseases. R. K Webster and P. S. Gunnell, eds. American Phytopathological Society, St. Paul, MN.

Bonman, J. M. 1992b. Durable resistance to rice blast disease-Environmental influences. Euphytica 63:115-123.

Bonman, J. M., Vergel de Dios, T. I., and Khin, M. M. 1986. Physiologic specialization of Pyricularia oryzae in the Philippines. Plant Dis. 70:767-769.

Chen, D. H., Zeigler, R. S., Leung, H., and Nelson, R. J. 1995. Population structure of Pyricularia grisea at two screening sites in the Philippines. Phytopathology 85:1011-1020.

Chen, H. L., Chen, B. T., Zhang, D. P., Xie, Y. F., and Zhang, Q. 2001. Pathotypes of Pyricularia grisea in rice fields of central and southern China. Plant Dis. 85: 843-850.

Correa-Victoria, F. J., and Zeigler, R. S. 1993. Pathogenic variability in Pyricularia grisea at a rice blast "hot spot" breeding site in eastern Colombia. Plant Dis. 77:1029-1035.

Dean, R. A., Talbot, N. J., Ebbole, D. J., Farman, M. L., Mitchell, T. K., Orbach, M. J., Thon, M., Kulkarni, R., Xu, J. R., Pan, H., Read, N. D., Lee, Y. H., Carbone, I., Brown, D., Oh, Y. Y., Donofrio, N., Jeong, J. S., Soanes, D. M., Djonovic, S., Kolomiets, E., Rehmeyer, C., Li, W., Harding, M., Kim, S., Lebrun, M. H., Bohnert, H., Coughlan, S., Butler, J., Calvo, S., Ma, L. J., Nicol, R., Purcell, S., Nusbaum, C., Galagan, J. E., and Birren, B. W. 2005. The genome sequence of the rice blast fungus Magnaporthe grisea. Nature 434:980-986

Flor, H. H. 1971. Current status of the gene-for-gene concept. Annu. Rev. Phytopathol. 9:275-296.

Fukuta, Y., Araki, E., Yanoria, M. J. T., Imbe, T., Tsunematsu, H., Kato, H., Ebron, L. A., Mercado-Escueta, D., and Khush, G. S. 2004. Development of differential variations for blast resistance in IRRI-Japan Collaborative Research Project. Pages 229-233 in: Rice Blast: Interaction with Rice and Control. S. Kawasaki, ed. Kluwer Academic Publishers, Dordrecht, The Netherlands.

Fukuta, Y., Koga, I., Ung, T., Sathya, K., Kawasaki-Tanaka, A., Koide, Y., Kobayashi, N., Obara, M., Yagana, H., and Hayashi, N. 2014. Pathogenicity of rice blast (Pyricularia oryzae Cavara) isolates from Cambodia. JARQ 48: 155-166.

Gilmour, J. 1973. Octal notation for designating physiologic races of plant pathogens. Nature 242:620.

Hayashi, N., Ando, I., and Imbe, T. 1998. Identification of a new resistance gene to a Chinese blast fungus isolate in the Japanese rice cultivar Aichi Asahi. Phytopathology 88:822-827.

Hayashi, N., and Fukuta, Y. 2009. Proposal for a new international system of differentiating races of blast (Pyricularia oryzae Cavara) by using LTH monogenic lines in rice (Oryza sativa L.). Pages 11-15 in: JIRCAS Working Report No. 63. Japan International Research Center for Agricultural Sciences, Tsukuba, Ibaraki, Japan.

Hayashi, N., Kobayashi, N., Vera Cruz, C. M., and Fukuta, Y. 2009. Protocols for the sampling of diseased specimens and evaluation of blast disease in rice. Pages 17-33 in: JIRCAS Working Report No. 63. Japan International Research Center for Agricultural Sciences, Tsukuba, Ibaraki, Japan.

Kawasaki-Tanaka, A., Hayashi, N., Yanagihara, S., and Fukuta, Y. 2016. Diversity and distribution of rice blast (Pyricularia oryzae Cavara) races in Japan. Plant Dis. 100:816-823.

Khan, M. A. I., Buiyan, M. R., Hossain, M. S., Sen, P. P., Ara, A., Siddique, M. A., and Ali, M. A. 2014a. Neck blast disease influences grain yield and quality traits of aromatic rice. C. R. Biol. 337:635-641. 
Khan, M. A. I., Sen, P. P., Buiyan, M. R., Kabir, E., Chowdhury, A. K., Fukuta, Y., Ali, M. A., and Latif, M. A. 2014b. Phenotypic screening and molecular analysis of blast resistance in fragrant rice for marker assisted selection. C. R. Biol. 337:318-324.

Khush, G. S. 1984. Terminology for rice growing environments. Pages 5-10 in: Terminology of Rice Growing Environments. International Rice Research Institute, Manila, Philippines.

Khush, G. S. 1997. Origin, dispersal, cultivation and variation of rice. Plant Mol. Biol. 35:25-34.

Kiyosawa, S. 1984. Establishment of differential cultivars for pathogenicity test of rice blast fungus. Rice Genet. Newsl. 1:95-97.

Kobayashi, N., Yanoria, M. J. T., Tsunematsu, H., Kato, H., Imbe, T., and Fukuta, Y. 2007. Development of new sets of international standard differential cultivars for blast resistance in rice (Oryza sativa L.). JARQ 41:31-37.

Koizumi, S. 2008. Durability of resistance to rice blast disease. Pages 1-10 in: Differential Systems for Blast Resistance for Stable Rice Production Environment, Vol. 53. Y. Fukuta, C. M. Vera Cruz, and N. Kobayashi, eds. Japan International Research Center for Agricultural Sciences (JIRCAS), Tsukuba, Ibaraki, Japan.

Le, M. T., Arie, T., and Teraoka, T. 2010. Population dynamics and pathogenic races of rice blast fungus, Magnaporthe oryzae in the Mekong Delta in Vietnam. J. Gen. Plant Pathol. 76:177-182.

Ling, Z. Z., Mew, T. V., Wang, J. L., Lei, C. L., and Huang, N. 1995. Development of near-isogenic lines as international differentials of the blast pathogen. Int. Rice Res. Notes 20:13-14.

Mackill, D. J., and Bonman, J. M. 1992. Inheritance of blast resistance in near isogenic lines of rice. Phytopathology 82:746-749.

Marchetti, M. A., Rush, M. C., and Hunter, W. E. 1976. Current status of rice blast in the southern United States. Plant Dis. 60:721-725.

Mekwatanakarn, P., Kositratana, W., Levy, M., and Zeigler, R. S. 1999. Sexual fertile Magnaporthe grisea rice pathogens in Thailand. Plant Dis. 83:939-943.

Mekwatanakarn, P., Kositratana, W., Levy, M., and Zeigler, R. S. 2000. Pathotype and avirulence gene diversity of Pyricularia grisea in Thailand as determined by rice lines near-isogenic for major resistance genes. Plant Dis. 84:60-70.

Noda, T., Hayashi, N., Van Du, P., Dinh, H. D., and Van, E. L. 1999. Distribution of pathogenic races of rice blast fungus in Vietnam. Ann. Phytopathol. Soc. Jpn. 65:526-530.

Odjo, T., Kawasaki-Tanaka, A., Noda, T., Ahohuendo, B. C., Sere, Y., Kumashiro, T., Yanagihara, S., and Fukuta, Y. 2014. Pathogenicity analysis of blast (Pyricularia oryzae Cavara) isolates from West Africa. JARQ 48:403-412.

Ou, S. H. 1985. Rice Diseases, 2nd ed. Commonwealth Mycological Institute, Kew, England.

Prabhu, A. S., Filippi, M. C., and Araújo, L. G. 2002. Pathotype diversity of Pyricularia grisea from improved upland rice cultivars in experimental plots. Fitopatol. Bras. 27:468-473.

Shahjahan, A. K. M. 1994. Practical approach to rice blast management in tropical monsoon ecosystems, with special reference to Bangladesh. Pages 465-488 in: Rice Blast Disease. R. S. Zeigler, S. A. Leong, and P. S. Teng, eds. International Rice Research Institute \& CABI Publication, Wallingford, U.K.
Silué, D., Tharreau, D., and Notteghem, J. L. 1992. Evidence of gene-for-gene relationship in the Oryza sativa-Magnaporthe grisea pathosystem. Phytopathology 82:577-580.

Simpson, E. H. 1949. Measurement of diversity. Nature 163:688.

Talbot, N. J. 2003. On the trial of a cereal killer: Investigating the biology of Magnaporthe grisea. Annu. Rev. Microbiol. 57:177-202.

Telebanco-Yanoria, M. J., Imbe, T., Kato, H., Tsunematsu, H., Ebron, L. A., Vera Cruz, C. M., Kobayashi, N., and Fukuta, Y. 2008. A set of standard differential blast isolates (Magnaporthe grisea (Hebert) Barr.) from the Philippines for rice (Oryza sativa L.) resistance. JARQ 42:23-34.

Telebanco-Yanoria, M. J., Koide, Y., Fukuta, Y., Imbe, T., Kato, H., Tsunematsu, H., and Kobayashi, N. 2010. Development of near-isogenic lines of Japonicatype rice variety Lijiangxintuanheigu as differentials for blast resistance. Breed. Sci. 60:629-638.

Thinlay, Zeigler, R. S., and Finckh, M. R. 2000. Pathogenic variability of Pyricularia grisea from the high- and mid-elevation zones of Bhutan. Phytopathology 90:621-628.

Tsunematsu, H., Yanoria, M. J. T., Ebron, L. A., Hayashi, N., Ando, I., Kato, H., Imbe, T., and Khush, G. S. 2000. Development of monogenic lines of rice for blast resistance. Breed. Sci. 50:229-234.

Tuite, J. 1969. Plant Pathological Methods, Fungi and Bacteria. Burgess Publishing, Minneapolis, MN

Valent, B., and Chumley, F. G. 1991. Molecular genetic analysis of the rice blast fungus Magnaporthe grisea. Annu. Rev. Phytopathol. 29:443-467.

Ward, J. H. 1963. Hierarchical grouping to optimize an objective function. J. Am. Stat. Assoc. 58:236-244.

Xia, J. Q., Correll, J. C., Lee, F. N., Marchetti, M. A., and Rhoads, D. D. 1993. DNA fingerprinting to examine micrographic variation in the Magnaporthe grisea (Pyricularia grisea) population in two rice fields in Arkansas. Phytopathology 83:1029-1035.

Xia, J. Q., Correll, J. C., Lee, F. N., Ross, W. J., and Rhoads, D. D. 2000. Regional population diversity of Pyricularia grisea in Arkansas and the influence of hos selection. Plant Dis. 84:877-884.

Yamada, M., Kiyosawa, S., Yamaguchi, T., Hirano, T., Kobayashi, T., Kushibuchi, K., and Watanabe, S. 1976. Proposal of a new method of differentiating races of Pyricularia oryzae Cavara in Japan. Ann. Phytopathol. Soc. Jpn. 42:216-219.

Zeigler, R. S., Cuoc, L. X., Scott, R. P., Bernardo, M. A., Chen, D. H., Valent, B., and Nelson, R. J. 1995. The relationship between lineage and virulence in Pyricularia grisea in the Philippines. Phytopathology 85:443-451.

Zeigler, R. S., Tohme, J., Nelson, R., Levy, M., and Correa, F. 1994. Linking blast population analysis to resistance breeding: A proposed strategy for durable resistance. Pages 267-292 in: Rice Blast Disease. R. S. Zeigler, S. A Leong, and P. S. Teng, eds. International Rice Research Institute \& CABI Publication, Wallingford, U.K.

Zhou, E., Jia, Y., Correll, J., and Lee, F. N. 2007. Instability of the Magnaporthe oryzae virulence gene AVR-Pitai alters virulence. Fungal Genet. Biol. 44 1024-1034. 